\title{
From Caesar to Tacitus: \\ Changes in Early Germanic Governance circa 50 BC-50 AD
}

\author{
Andrew T. Young \\ College of Business and Economics \\ West Virginia University \\ Morgantown, WV 26506-6025 \\ ph: 3042934526 \\ em: Andrew.Young@mail.wvu.edu
}

Latest Version: November 2014

JEL Codes: D72, N43, N93, P16,

Keywords: governance institutions, constitutional exchange, antiquity, early Germanic peoples, the Roman Empire, political economy, Julius Caesar, Tacitus, roving versus stationary bandits, ancient economic history 


\title{
From Caesar to Tacitus: Changes in Early Germanic Governance circa 50 BC-50 AD
}

\begin{abstract}
Julius Caesar and Cornelius Tacitus provide characterizations of early Germanic (barbarian) society around, respectively, $50 \mathrm{BC}$ and $50 \mathrm{AD}$. The earlier date corresponds to expansion of Rome to the Rhine and Danube. During the subsequent century Germanic governance institutions changed in a number of ways. In particular, (1) temporary military commanders elected from the nobility gave way to standing retinues under the leadership of professional commanders, (2) public assemblies met more frequently and regularly, (3) councils made up of nobility gained agenda control in the assemblies, and (4) these councils relinquished their control over the allocations of land. I account for these constitutional exchanges in light of Rome's encroachment upon Germania. In particular, it brought new sources of wealth and also constraints on the expansion of Germans into new lands. Incentives favored a reallocation of resources away from pastoralism and towards both sedentary farming and raids across the frontier.
\end{abstract}

JEL Codes: D72, N43, N93, P16,

Keywords: governance institutions, constitutional exchange, antiquity, early Germanic peoples, the Roman Empire, political economy, Julius Caesar, Tacitus, roving versus stationary bandits, ancient economic history 


\section{Introduction}

The emergence of government out of anarchy has intrigued political thinkers at least since

Thomas Hobbes and John Locke wrote in the seventeenth century. Modern political philosophers have utilized state of nature thought experiments to consider which sorts of emergent government are permissible (Nozick (1974), Rothbard (1998 [1982]), Rawls (1999 [1971])). Public choice economists have advanced social contract theory with similar experiments (Buchanan and Tullock (1962) and Buchanan (1975)) and they have also addressed questions about how governments actually emerge from anarchy (de Jasay $(1985,1990,1997)$ and Mueller $(1982))^{1}$

In seeking answers to the latter questions, researchers cannot rely on stylized states of nature that exist nowhere save for their imaginations. To that end, some researchers have sought to document historical expansions of existing governments into previously anarchic areas of society. For example, Benson (1990, 1994, 1998) and Ekelund and Dorton (2003)) study the evolution of English law enforcement and the role of the state. Other researchers have documented how constitutions have been adopted in areas that initially lacked effective government authority such as prisons (Skarbek, 2011), seafaring piratical communities (Leeson, 2009a), and the medieval Hanseatic League of traders (Fink, 2011).

Of course, being able to document the emergence of government from scratch - from a true state of anarchy - would be ideal. Unfortunately, true states of nature are difficult to find in the modern world. When something akin to a state of nature society is documented, it is often within or surrounded by more or less modern states. For example, when Evans-Pritchard (1947 [1940]) made his 1930s observations on the Nuer people, centered in southern Sudan, these

\footnotetext{
${ }^{1}$ For an excellent survey of the economics of anarchy, both theoretical and empirical, see Powell and Stringham (2009).
} 
people were living in the midst of (or closely surrounded by) British, Egyptian, and Ethiopian political structures. Also, such societies are often conquered or otherwise absorbed into existing governments; they are taken out of anarchy.

The most interesting cases of government emergence from anarchy are prehistoric, and almost by definition so. In this paper I try to exploit an instance of a historic society coming into contact with, but not conquering, a prehistoric society located in a geographically distinct and large territory. In particular, I take advantage of two remarkable accounts by Romans of northern barbarians - in particular, those of Julius Caesar in his Commentarii de Bello Gallico and of Cornelius Tacitus in the Germania. These accounts are based on observations that bookend a roughly 100 year period (50 BC-50 AD) that begins with Caesar's conquest of Gaul and the establishment of Rome's effective borders to the east and north as, respectively, the Rhine and Danube rivers. ${ }^{2}$ Beyond the Rhine and the Danube lay Germania, a vast area that roughly encompassed modern Germany, Denmark, Poland, Slovakia, the Czech Republic, half of Hungary, and a part of Austria. Germania was sparsely populated by barbarians who largely spoke German dialects. From Caesar to Tacitus we get a glimpse of the early institutions of Germanic governance and how they changed in the century following the expansion of Roman civilization into Gaul.

Caesar's observations suggest a Germania that was essentially anarchic, with tribes and confederacies that operated without much in the way of constitutions. Rather, they largely relied on conventions that facilitated a minimal level of political action, both in terms of the extent of such action and its frequency. Alternatively, in Tacitus' later account we find that governance institutions had evolved in important ways. Germanic constitutions had become more

\footnotetext{
${ }^{2}$ Some of the details provided by Tacitus in the Germania may be based on observations made during the years up to $100 \mathrm{AD}$; more on this below.
} 
sophisticated and the extent and frequency of political action had increased. These observations one from each side of the millennium's turn - provide us with a fascinating look at how Germanic barbarian governments began to emerge. These emergent governments represent, along with the (much better documented and understood) institutions of the Roman Empire, an important part of Western civilization's political roots. ${ }^{3}$ In this paper I provide an account of these changes in governance institutions and constitutional exchanges that make them intelligible.

Interestingly, while Caesar's conquering of Gaul created changes in external conditions that I argue were fundamental causes of the Germanic institutional changes, these changes occurred in a vast geographic territory that Rome did not have sufficient incentives to attempt conquering. To wit: the observed evolution and emergence of the barbarian governance institutions was not simply a means to avoid the encroachment of a government from without. Rather, Roman expansion halted because the net benefits to expansion became too small. Furthermore, net benefits to further expansion were small because, on the margin, gross benefits (rather than costs) were small. To the east of the Rhine lay an intermediate zone between what archaeologists refer to at the La Tène and Jastorf material cultures. The former of these was largely located in Gaul; the latter to the east and north. As Heather (2006, pp. 56-57) explains:

As well as villages, La Tène Europe had also generated, before the Roman conquest, much larger settlements, sometimes identified as towns[.] ... In some La Tène areas coins were in use, and some of its populations were literate. [...] All of this rested on an economy that could produce sufficient foods surpluses to support warrior, priestly and artisan classes not engaged in primary

\footnotetext{
${ }^{3}$ A recent example of a political economy analysis of the Roman Republic's constitution is Posner (2010).
} 
agricultural production. Jastorf Europe, by contrast, operated at a much starker level of subsistence, with a greater emphasis on pastoral agriculture and much less of a food surplus. Its population had no coinage or literacy, and [...] had produced no substantial settlements - not even villages. Also, its remains produced almost no evidence for any kind of specialized economic activity (Heather, 2006, pp. 56-57).

The above passage supports two conclusions relevant to the arguments of this paper. First, the Germanic peoples that Caesar encountered were indeed living in something close to a state of nature. Second, the halt of Roman expansion occurred first and foremost "around a major faultline is European socio-economic organization" beyond which "the difficulties involved in incorporating the next patch of territory, combined with the relative lack of wealth that can be extracted it, make further conquest unattractive” (Heather, 2006, p. 57). Germanic governance involved in response to the encroachment of Rome; but not under a serious threat of absorption into Rome.

The expansion of the Roman Republic to the Rhine and Danube rivers brought Germanic peoples into contact with new sources of wealth and also constrained their expansion into new lands. By the time of Tacitus the Roman Republic had become the Roman Empire and a number of changes in Germanic governance institutions had occurred. In particular, (1) temporary military commanders elected from the nobility yielded to standing retinues under the leadership of professional commanders; (2) public assemblies met more frequently and regularly; (3) councils made up of the nobility had acquired agenda control in the public assemblies; and (4) the nobility had relinquished their control over village land allocations. I argue that these changes are made intelligible by constitutional exchanges that were net beneficial to both 
Germanic nobility and freemen. In particular, these constitutional exchanges occurred against a backdrop of incentives that had changed in ways that favored a reallocation of resources away from pastoralism and towards sedentary farming and raiding excursions across the frontier.

“Mutual gains from constitutional exchange occasionally emerge, which can be realized by amending the preexisting constitutions” (Congleton, 2011, p. 9). This is the perspective from which the analysis of Germanic governance institutions from Caesar to Tacitus below proceeds. While a number of historians have noted the institutional differences across the accounts of Caesar and Tacitus - Thompson (1965) being an excellent example - this paper provides, to my knowledge, the first economic analysis of non-Roman, pre-Medieval political institutional change in Europe. My account of the institutional details found in both the Commentarii de Bello Gallico and the Germania focuses on decision-making rules and the divisions of governance (checks and balances). I then describe the changes in incentives created by Rome's expansion, which created new constraints on available land as well as new sources of nearby and potentially extractable wealth for the barbarians. Understanding these pre-Medieval barbarian institutions and how they evolved is interesting and important because they provided foundations for the successor kingdoms to the Empire.

I will proceed along the following lines. First, in section 2, I will elaborate on the Germanic societies observed by Caesar circa 50 BC. Then I will do the same for the circa 50 AD societies characterized by Tacitus in his Germania in section 3. In section 4 I will summarize the salient changes in Germanic governance institutions that we witness from Caesar to Tacitus. My attempt to makes these changes intelligible in terms of constitutional exchanges motivated by the encroachment of Rome is then made in section 5. I conclude in section 6. 


\section{Germanic Peoples circa 50 BC}

Julius Caesar published his Commentarii de Bello Gallico (Gallic War) following his military campaigns from $58 \mathrm{BC}$ to $50 \mathrm{BC}$. These campaigns led to the establishment of the Rhine to the east and the Danube to the north as borders between the Roman Empire and Germania.

Following his defeat of the Helvetti, Caesar came into conflict with the Suebi, the "largest and most warlike nation among the Germans”. The Suebi were led by a king (rex) named Ariovistus (Caesar, Book IV, p. 181; Book I, pp. 49-87). Caesar attributes to the Suebi "a hundred cantons from which they draw one thousand armed men yearly” and the settlement of 120,000 Germans across the Rhine in Gaul (Caesar, Book IV, p. 181; Book I, p. 47). ${ }^{4}$

The Roman governor's recordings make it clear that Ariovistus was not a standing king. Rather, he was a member of the nobility who had temporarily been granted military command: When a state makes or resists aggressive war officers [magistratus] are chosen to direct the same, with the power of life or death. In time of peace there is no general officer of state [communis magistratus], but the chiefs [princepes] of the districts and cantons do justice among their followers and settle disputes. Acts of brigandage committed outside the borders of each several state involve no disgrace[ ....] And when any of the chiefs has said in public assembly [concilio dixit] that he will be leader [dux], "Let those who will follow declare it," then all who approve the cause and the man rise together to his service and promise their own assistance, and win the general praise of the people (Caesar, Book VI, p. 349).

\footnotetext{
${ }^{4}$ The initial invasion appears to have consisted of 15,000 Germanic people.
} 
A king such as Ariovistus was a temporary leader chosen form the nobility (leading men) and, having put forth his cause at a public assembly, elected by voluntary consent of the free population. That such a king was specifically a military leader is implied, so such elections likely only occurred in times of war; or to organize aggressive, wealth-extracting raids on foreigners. ${ }^{5}$ And only in the case of the former did they actually have any coercive "power over life or death". Otherwise such a king relied on the "promise[s]" of those who chose to follow them.

The "public assembly" mentioned above, where a princeps could put himself up for election by acclamation to the role of a duc is the only mention of a gathering of citizens generally - something akin to the Assembly of Warriors later described by Tacitus. (See section 3 below.) Otherwise we find reference in Caesar's account only to more exclusive councils of the leading men from various tribes. Such a council appears to be largely analogous to the Council of Leading Men that we encounter in Tacitus' account. (Again, see section 3 below.)

Regarding these councils of tribal chiefs, in Caesar's descriptions we find mention of only one regular meeting (Caesar, Book VI, p. 347):

No man has a definite quantity of land or estate of his own: the magistrates and chiefs [magistratus ac principes] every year assign to tribes and clans [gentibus congnationibusque hominum] that have assembled together as much land and in such place as seems good to them, and compel the tenants after a year to pass on elsewhere. ${ }^{6}$

\footnotetext{
${ }^{5}$ As we shall see below (in section 3 ) by the middle of the first century AD the role of Germanic kings as violent entrepreneurs (or formeteurs: Congleton (2011b)) has grown in importance. Note that proximate to the reference to brigandage Caesar refers to a dux while rex is reserved for a small number specific individuals mentioned, including Ariovistus who had been "saluted as king and friend by the Senate" in 59 BC, the year of Caesar's consulship (Caesar, Book I, p. 55). Tacitus, as we shall see, is clearer regarding his use of dux versus rex and the difference between the two.

${ }^{6}$ On its face this arrangement lacks incentives to treat the land as a long-lived asset. We are therefore not surprised by Caesar’s observation that: "For agriculture, they [the Germanic people] have no zeal.” Interestingly, Caesar records for us the Germanic people's rationales: fears that (1) "they may be tempted by continuous association to
} 
Aside from an annual meeting to allocate farmland, Caesar's account suggests that council meetings occurred only under extraordinary circumstances, such as when there was a military threat (Caesar, Book IV, p. 205):

The Suebi, when they had discovered by means of their scouts that a bridge was being built [by Caesar to cross the Rhine], held a convention [concilio] according to their custom, and dispatched messengers to all quarters, ordering the people to remove from their towns, to lodge their children and all their stuff in the woods, and to assemble in one place all men capable of bearing arms. This governance body thus played a role in facilitating intertribal collective action once a year in regards to the allocation of arable land, and otherwise only during times of emergencies: "In peacetime no council higher than the councils of the pagi [individual tribes or villages] can be said with certainty to have existed” (Thompson, 1965, p. 13). ${ }^{7}$

Overall, Caesar paints a picture of a Germanic society with governance institutions that, beyond the individual tribe or clan, were primitive and operated irregularly and infrequently.

The kindred [tribe or clan] [...] was the fundamental entity in society. The kindreds only loosely knit together, and in peacetime there seems to have been

\footnotetext{
substitute agriculture for their warrior zeal"; (2) "that they may become zealous for the acquisition of broad territories, and so the more powerful may drive the lower sort from their holdings"; (3) "that they may build with greater care to avoid the extremes of cold and hear"; and (4) "that some passion for money may arise to be the parent of parties and quarrels." Reasons (2), (3) and (4) are linked by Caesar to the general desire "to keep common people in contentment, when each man sees that his own wealth is equal to that of the most powerful." By Caesar's account, then, at least some Germanic people valued distributive equality. However, note that the early Germanic people were largely pastoral and "although the pastures were unenclosed and common to everyone, we may assume that the herds were held on an individual basis [...]" (Thompson, 1965, p. 9).

${ }^{7}$ Caesar, when referring to a political rather than kindred unit, uses the word pagus which can be translated as "a village or country district; a canton" (University of Notre Dame online Latin to English dictionary: http://www.archives.nd.edu/cgi-bin/lookup.pl?stem=pagus; accessed on May 5, 2014). He is clearly referring to a small unit, corresponding to a tribe or clan. This is the interpretation of Thompson (1965, ch. 1, sect. 2). Also, note that Caesar (quoted above) attributes to the Suebi "a hundred cantons from which they draw one thousand armed men yearly.” The pagus, then, was clearly a very small unit relative to what was represented by a king such as Ariovistus; or by the council of principes at which such a rex would be elected.
} 
no public authority to weld them all into a unity. Slavery was still in an incipient stage of growth, and there were no public institutions of coercion. In all, so primitive was Germanic society that we cannot disregard Caesar’s remark that the life of the Germans was one of poverty, want, and hardship (Thompson, 1965, p. 17).

Caesar’s characterization of a Germanic existence as one of “poverty, want, and hardship” (inopia, egestate, patientia) (Caesar, Book VI, p. 350) is reminiscent of Hobbes’ characterization of life in a state of nature as "solitary, poor, nasty, brutish and short”. More importantly, the lack of intertribal governance institutions and the lack of legitimized coercion on the part of those institutions suggests that Germanic society circa 50 BC closely resembled a state of nature.

A century later, however, institutional arrangements had changed significantly; and we have a record of those changes thanks to the account of the Roman historian Tacitus.

\section{Germanic Peoples circa 50 AD}

Gaius Cornelius Tacitus published his Germania around 98 AD. ${ }^{8}$ He likely had never himself set foot in Germania and it is also likely that he relied heavily on the Elder Pliny’s lost Bella Germaniae (Gudeman, 1900). This would suggest that Tacitus' characterization of Germanic societies applies to the period of time between 50 and 54 AD. Of course, we cannot rule out the influence of other sources and, perhaps, even Tacitus’ own experiences, so some details contained with the Germania may be based on the later first century AD. Still, the Germania provides an account of Germanic governance 100 to 150 years after Caesar’s observations.

\footnotetext{
${ }^{8}$ References to the Germania text will generally be from the 1970 Penguin edition; I have used the 1869 Macmillan and Co. edition to confirm the original Latin for key words.
} 
Tacitus provides a wealth of details regarding the political institutions of the Germans. The details fit into the broad contours of the King and Council template of divided government that is elaborated on by Congleton (2001, 2011a):

It is a method of governance that has neither an unrestricted executive (leviathan or dictator) nor an unrestrained parliament (legislature, council, committee, or diet). [...] It divides up policy-making responsibility between a branch of government headed by one person, and another branch in the form of a committee composed of several members having more or less equal authority. I refer to this very general and ancient constitutional template as 'king and council' (2001, p. 193).

I refer to the broad contours of this template because, as we shall see, the northern barbarians had both general councils that included all freemen and more exclusive executive councils. Using the language of Thompson (1965), I shall refer to the general and executive councils, respectively, as the Assembly of Warriors and Council of Leading Men. In addition to the Assembly and Council, the peoples of Tacitus' Germania also had two types of kings: one elected based on prowess as a warrior (dux) and the other based on noble birth (rex). Tacitus draws a clear distinction between these two types of kings, the former of which was "clearly a later, more developed, and less egalitarian for of institution” that, regardless of the use of the word rex in the Gallic War, has "no parallel to it in Caesar" (Thompson, 1965, p. 33). When Roman observers employed the term rex - as did both Caesar and Tacitus - they meant to imply nobility and an association with the sacral.

\subsection{Assembly of Warriors}


The Assembly of Warriors was the more popular of the governance structures. It included all male citizens, of which three ranks existed: freemen, nobles, and then kings and/or military chiefs. The inclusion of all citizens in no way implied a type of universal suffrage across a Germanic nation. There remained both slaves and freedmen, neither of which were considered citizens and whom together likely constituted the largest part of the population. ${ }^{9}$ Tacitus (ch. 25, p. 122) notes that "Freedmen [liberti] rank little higher than slaves[.]" His description of slaves themselves strikes the modern reader as akin to serfs of the Middle Ages: "Each has control of a holding or home of his own [and] the master demands from him a stated quantity of grain, livestock, or cloth, as he would from a tenant” (Tacitus, ch. 25, p. 122).

A clear distinction in ranks, aside from the principes, is notably not elaborated upon in Caesar's account of Germanic people a century earlier. This is undoubtedly due in part simply to the author's choice of which details to report and which to omit; likely there were similar degrees of social stratification circa 50 BC. That being said, Caesar does elaborate in some detail upon the "two classes of persons of definite account and dignity" amongst the neighboring Gauls and the fact that "[a]s for the common folk, they are treated almost as slaves” (Caesar, Book VI, p. 335). ${ }^{10}$ (Explicit reference to slaves is never made in by Caesar in regards to Germanic peoples.) Therefore, one may conclude that formal social stratification had increased during the subsequent century.

\footnotetext{
${ }^{9}$ To my knowledge there is no reliable evidence on how large a part citizens (freemen and nobles) were of German populations in the first century AD. However, Heather (2010, p. 66) reports that, in the sixth century, "Some not very good Ostrogothic and Lombard evidence [suggests that] freemen amounted to something like a quarter or a fifth of weapon-bearing males[.]" The reference to "weapon-bearing" implies that slaves are excluded. While a lot can change over 500 years, the ranks of Germanic successor states seem to have changed little (the exception being that kings by then constituted a distinct and permanent rank in and of themselves). Again, then, it seems most likely that citizens constituted a minority of first century Germans.

${ }^{10}$ These two classes of distinction are Druids and knights. The former were a class of priests who also acted as judges "in almost all disputes, public and private" and were excused from military service (Caesar, Book VI, p. 337). Knights, as the term would suggest, were a warrior class.
} 
Thompson (1965) appends “of Warriors” to what Tacitus’ refers to as simply the assembly (concilium) because the bearing of arms and military obligation appear to be intrinsic to membership. The rite of passage into manhood involved the bestowing of weapons "in the presence of the Assembly": "the first distinction publicly conferred upon a youth, who now ceases to rank merely as a member of a household and becomes a citizen” (Tacitus, ch. 13, p. 112). And to "throw away one's shield in battle is the supreme disgrace, and the man who has thus dishonoured himself is debarred from attendance at sacrifice or assembly” (Tacitus, ch. 6, pp. 106-107). ${ }^{11}$

The Assembly of Warriors met approximately monthly: "on certain particular days either shortly after the new moon or shortly before the new moon” (Tacitus, ch. 11, p. 110). The Assembly debated "major affairs" (as opposed to "matters of minor importance" that could be taken up by the independently by the Council of Leading Men - see below). This likely included declarations of peace or war, as was the case when Caesar made his observations (Thompson (1965, p. 31); Caesar (Book VI, p. 205 - see below). The Assembly was also "competent to hear criminal charges, especially those involving the risk of capital punishment" and could "elect, among other officials, the magistrates [principes] who administer justice in the districts and villages [pagos vicosque]” (Tacitus, ch. 12, pp. 111-112). Decisions were determined by a form of acclamation: "If a proposal pleases them, the people shout their dissent; if they approve, they clash their spears” (ch. 11, p. 111). Criminal charges could result in fines, part of which would go towards restitution for victims; another part of which would be expropriated by the nobility. (This last point will be elaborated on in section 5 below.)

\footnotetext{
${ }^{11}$ Tacitus furthermore relates: "When the assembled crowd thinks fit, they take their seats fully armed" (ch. 11, p. 110).
} 


\subsection{Council of Leading Men}

While the Assembly of Warriors had say on major affairs, a Council of Leading Men could handle on its own "matters of minor importance” (Tacitus, ch. 11, p. 110). Furthermore, "even where the commons [i.e., the Assembly of Warriors] have the decision, the subject is considered in advance by the chiefs [principes]” (Tacitus, ch. 11, pp. 110). As such, while the Council of Leading Men did not ultimately decide major affairs, even in regards to these it had agenda control over what was taken up by the Assembly of Warriors. Tacitus also makes a remark suggesting the existence of a chief among chiefs, i.e., an executive or spokesman for the Council (Tacitus, ch. 11, p. 111):

When the assembled crowd thinks fit, they take their seats fully armed. Silence is then commanded by the priests, who on such occasions have power to enforce obedience. Then such hearing is given to the king or state-chief [rex vel princeps] as his age, rank, military distinction, or eloquence can secure more because his advice carries weight than because he has the power to command. If a proposal pleases them [the Assembly], then people shout their dissent; if they approve, they class their spears.

Whether this rex vel princeps was a more or less official is unclear, but what is clear from the above passage is that the Council of Leading Men set the agenda for the General Assembly which, in turn, rendered its decisions on the items of that agenda.

\subsection{Kings: Reges and Duces}


Tacitus records that the Germanic peoples "choose their kings [reges] for their noble birth, their commanders [duces] for their valour” (ch. 7, p. 107):

The power even of the kings [regibus] is not absolute or arbitrary. The commanders [duces] rely on example rather than on the authority of their rank - on admiration they win by showing conspicuous energy and courage and by pressing forward in front of their own troops. Capital punishment, imprisonment, even flogging, are allowed to none but the priests.

Unlike in Caesar's account, in that of Tacitus we find specific mention of priests on several occasions. Tacitus associates both the priests and the reges with the sacral (ch. 10, p. 110): [The Germanic peoples] try to obtain omens and warnings from horses. These horses are kept at the public expense in the sacred woods and groves [....] They priest and the king, or the chief of state [rex vel princeps civitatis comitantur], yoke them to a sacred chariot and walk beside them taking note of their neighs and snorts. ${ }^{12}$

Furthermore, as mentioned above, at the Council of Leading Men such a king spoke with authority "more because his advice carries weight than because he has the power to command (ch. 11, p. 111). ${ }^{13}$

Alternatively, duces are never associated with the sacral in Tacitus’ account. They are instead portrayed as violent formeteurs: individuals who consciously organized warriors into retinues that acted as profit-seeking entities (Congleton, 2011b). A commander organized a

\footnotetext{
${ }^{12}$ Evidently these horses were maintained and kept "undefiled by any toil in the service of man” (ch. 9, p. 108). Not only do we have evidence of Germanic assemblies becoming more regular in their meetings; we also have evidence of a continuously maintained public good.

${ }^{13}$ The above-mentioned horses represent, aside from law and order and defense services during times of war, the only explicitly mentioned provision of a public good by the governance bodies of Germanic society.
} 
retinue of warriors as a means of "war and plunder” (Tacitus, ch. 14, p. 113). In the case of the former, the commander and his retinue provided defense services. In the case of the latter, the goal was wealth extraction, pure and simple:

A German is not so easily prevailed upon to plough the land and wait patiently for harvest as to challenge a foe and earn wounds for his reward. He thinks it tame and spiritless to accumulate slowly by the sweat of his brow what can be got quickly by the loss of a little blood (Tacitus, ch 14, pp. 113-114).

Tacitus likely exaggerates the innate tendencies of Germans towards laziness in productive activities and violence in their stead, but we can infer that the returns to violent rent extraction were, for Germanic freemen, often higher than those associated with the peaceful creation of wealth. These returns could be from raids, which were purely extractive, or from the provision of defense services to Germans facing a threat. Regarding the latter Tacitus remarks on "a national custom for gifts of cattle or agricultural produce to be made to the chiefs, individual citizens making voluntary contributions for this purpose” (ch. 14, p. 114). Thompson (1965, p. 54) interprets these gifts from the population at large as payments in exchange for the standing provision of defense services.

The oath-bound relationship between a commander and his retinue was clearly different than kin-based relationship between a king and his clan. A Germanic rex had a measure of authority through his noble birth and an association with the sacral. Furthermore, for Romans like Tacitus the word rex "implied a moral content: a king should be able to rule himself as well as others” (Wallace-Hadrill, 1971, p. 3). ${ }^{14}$ Alternatively, a warrior was sworn to a commander’s

\footnotetext{
${ }^{14}$ There is evidence of Germanic peoples adopting the Latin "rex" with an understanding of its sacral connotation. In Britain, barbarians had introduced coinage, pre-dating the Claudian conquest (43 AD), on which the "word most often used, REX, is strange to Roman coinage, and must have been employed with a real sense of its meaning" (Haverfield, 1912, loc. 209).
} 
retinue only so far as it was in his interest to be so. Tacitus describes a competitive labor market where the supply of warriors interacted with the demand on the part of duces for their services: "there is great rivalry, both among the followers to obtain the highest place in their leader's estimation and among the chiefs for the honour of having the biggest and most valiant retinue” (ch. 13, p. 112). Tacitus refers to place in the leader's estimation and honour but yet his further remarks suggest more mundane motives (ch. 14, p. 113):

[A] large body of retainers cannot be kept together except by means of violence and war. They are always making demands on the generosity of their chief, asking for a coveted war-horse or a spear stained with the blood of a defeated enemy. Their meals, for which plentiful if homely fare is provided, count in lieu of pay. The wherewithal for this openhandedness comes from war and plunder.

Organized by duces into retinues, warriors' marginal products could be higher than in alternative, non-violent pursuits; and if a particular commander did not remunerate in accordance with those marginal products then a warrior had competing duces to which he could turn.

The descriptions above suggest that these retinues functioned as clubs with self-enforcing constitutions (Leeson, 2011). ${ }^{15}$ The commander, functioning as formeteur, organized a group of warriors and then, functioning as a Kirznerian (1973) entrepreneur, provided them with leadership in the identification and pursuit of profit opportunities. Operating within a competitive market of other formeteur/entrepreneurs, warriors remained in a particular retinue only so long as it was in their interest to do so. However, they were residual claimants on that retinue's revenues (distributed under the guise of the commander's largesse). These revenues depended on each

\footnotetext{
${ }^{15}$ The economy theory of clubs is rooted in the work of Buchanan (1965); the subsequent and associated literature is surveyed by Sandler and Tschirhart (1997).
} 
warrior playing by the rules; in particular, following the commands of his dux and not shirking during battle. One can easily imagine the mechanisms within a retinue by which one warrior's shirking would likely have been punished by the others! Furthermore, recall Tacitus’ remark that, for a warrior, to "throw away one's shield in battle is the supreme disgrace, and the man who has thus dishonoured himself is debarred from attendance at sacrifice or assembly” (Tacitus, ch. 6, pp. 106-107). There may as well have been, then, mechanisms external to a given retinue that also contributed to its constitution being self-enforcing. Shirking may have meant exclusion from the religious practices of Germanic society as well as the institutions of popular governance.

Of course, competition in the provision of violence can easily turn into competition by use of violence. These commanders were the forerunners of the barbarian kingships that supplanted the Western Roman Empire in the fifth and sixth centuries. As Wolfram (1997, p. 15) states: “Though [Tacitus] appears to describe the simultaneous existence of royal and military (ducal) authority, he was in fact recording two forms of Germanic kingship that supplemented, indeed succeeded, one another.” According to Heather (1996, p. 66), “the rise of groups of specialist armed retainers was a social development of the greatest importance. [...] In the bulk of so-called Free Germany [...] weapon burials became common from at least the first century AD.” Archaeology has demonstrated the increasing prevalence of such burials and, by the fourth century: "The degree of evident military specialism [...] not at a first-century Tacitean comitatus [retinue] of part time peasant soldiers, but at a hierarchically structured chief’s retinue” (p. 68). It is unclear what Heather's characterization of retinue members as "part time" is based upon. Neither Tacitus nor, to my knowledge, any alternative contemporary source makes explicit statements to that extent. Thompson (1965, p. 50), alternatively, states that by the end of the first 
century a "leader of a retinue had [...] transformed his relationship with his companions (comites) into something like a permanent one.” Regardless, what seems clear is the fact that, by the middle of the first century AD, these retinues were on an evolutionary path of increasing hierarchical military specialism. The most successful of these hierarchically structured retinues e.g., those under Clovis the Frank in the fifth century - would later consolidate less successful counterparts into the successor kingdoms of early medieval Europe.

\section{From Caesar to Tacitus: Summarizing the Changes}

The changes in early Germanic governance institutions that occurred from approximately $50 \mathrm{BC}$ to about $50 \mathrm{AD}$ are summarized in table 1. The popular Assembly of Warriors began to meet more frequently and regularly. Also, a more exclusive and elite Council of Leading men gained autonomous authority on a limited range of judicial matters, as well as agenda-setting power in the larger Assembly.

There was also a shift in executive power from tribal-based, sacral kingships and towards retinues organized under military commanders. During Caesar's time, military commanders were drawn from royal (or at least noble) families at times of emergency and only for the duration of the emergency. Their tenures, then, were both short-lived and irregular. However, Tacitus describes commanders whose standing retinues provided protection services during war and also pursued profit-seeking raids as a matter of course. These comitati were constitutionally selfenforcing and their commanders' tenures were founded on warriors’ respect for their organizational skills and war-making prowess.

In broad strokes, what we witness from Caesar to Tacitus is twofold. First, there is the regularization and specialization of legislative and judicial governance in (approximately) 
monthly meetings of the Assembly of Warriors; with minor matters and agenda-setting power delegated to the more exclusive Council of Leading Men. Second, there is the secularization and constitutionalization of executive power. Whereas a rex yielded authority based on his noble lineage and his association with the sacral - and exercised executive power during really only times of war-duces organized standing retinues within which obedience to a commander was constitutionally self-enforcing based on its being mutually beneficial to the commander and his warriors alike.

Regarding the powers of the Assembly of Warriors vis-à-via the Council of Leading Men, the former gained the rights to adjudicate major criminal charges and decide on "major" affairs. Though not elaborated on by Tacitus, these major affairs likely included the allocation of land, previously a power delegated to the Council. Whether there were still yearly reallocations to the villages, as Caesar noted in the first century BC is unclear. Tacitus (ch. 26, p. 122): Lands proportioned to their own number are appropriated in turn for tillage by the whole body of tillers. They then divide them among themselves according to rank; the division is made easy by the wide tracks of cultivable ground available. These ploughlands are changed [mutant] yearly, and still there is enough to spare. The fact is that although their land is fertile and extensive, they fail to take full advantage of it because they do not work sufficiently hard.

Here, "the whole body of tillers" suggests a decision made by the broad assembly. The word mutant may mean exchanged, altered, or moved. Given that Tacitus subsequently comments that "there is enough [land] to spare", he may simply be referring to a relatively loose pattern of crop rotation. There is no explicit mention of tenants being "compelled to move on", as had been the case with the Council of Leading Men when Caesar wrote. Also, when Tacitus notes that the 
German's “land is fertile and extensive” but that they do not "take full advantage of it” due to a lack of effort, he might mean in terms of farming itself or the labor necessary to clear arable land in the first place.

Tacitus (but not Caesar) also mentions that the Assembly of Warriors appointed the village magistrates from amongst the leading men. Alternatively, while the leading men could merely call the Assembly to meet during the time of Caesar, a century later the Council exercised agenda control at the Assembly's regular meetings.

While the Council gained agenda control in the Assembly, its membership of principes lost more than the power to make annual allocations of arable land. The emergence of commanders elected first and foremost for their military and organizational skills represented a loss to the nobility. In Caesar's time, the commanders during times of war or of raiding expeditions were elected exclusively from the principes if not the reges. Tacitus, however, records a Germania characterized by competition amongst profit-seeking retinues where success depended on the specialized formeteur/entrepreneur $d u x$.

The transition from kings and, during times of war, military leaders whose authorities were rooted in nobility and the sacral to formeteur/entrepreneur-led retinues is an interesting part of the evolution of Western government. These hierarchically structured and constitutionalized rent-seeking bodies were the precursors to the successor kingdoms to the Western Roman Empire. Furthermore, for the barbarians of Germania these retinues represented the first tentative steps out of something that very much resembled a state of nature.

Olson (1993, p. 567) characterizes anarchy by "uncoordinated competitive theft by 'roving bandits'[.]' For Olson, the emergence of a government out of a state of nature involves a "stationary bandit" who decides to monopolize theft and, in doing so, gain an encompassing 
interests in his domain. It behooves such a stationary bandit to provide law and order and other public goods to increase the wealth base from which they extract. As long as the increase in total wealth is greater than the increase in the amount extracted, both the bandit and the people in his domain can be made better off by this movement out of anarchy and into life under an autocratic government.

Olson explicitly characterizes a world of roving bandits as anarchic. These bandits exist and do what they do precisely because of a lack of governance in the state of nature. From the perspective of the communities they raided (e.g., in the Gallic provinces west of the Rhine) the comitati described above were essentially roaming bandits. Yet they themselves emerged noncoercively from the institutions of early Germanic governance. In Caesar's time, a leading man could aspire at the public assembly to command a raid: "Let those who will follow declare it." A century later duces led standing, profit-seeking retinues. These roving retinues were the precursors of the first stationary barbarian kingdoms. ${ }^{16}$ If not governments, they were governance organizations with self-enforcing constitutions; a meaningful step out of the state of nature that, for Germanic peoples, predated the scenario envisioned by Olson.

\section{Accounting for the Changes in Early Germanic Governance}

Regarding the institutional changes that we see from Caesar to Tacitus, the principal ones to account for are:

\footnotetext{
${ }^{16}$ Leeson (2007b, 2009a, and 2009b) elaborates on eighteenth century pirate outfits as constitutionalized roving bandits. Leeson has the benefit of much better documentation of the workings piratical governance (including formal constitutions). Alternatively, these pirate outfits began and ended as private and theft-based. In part, what makes the early Germanic retinues fascinating is that their governance institutions can be linked to those of early medieval kingdoms.
} 
- the transition from temporary military commanders elected from the nobility to standing retinues under the leadership of formeteur/entrepreneurs;

- the more frequent and regular meeting of a public assembly;

- the granting of agenda control in the public assembly to the nobility;

- the relinquishing of land allocation decisions by the nobility.

I argue that, following the expansion of the Roman Republic to its Rhinean and Danubian frontiers, Germanic peoples were both exposed to new sources of wealth and faced increased scarcity of land. These combined created incentives to specialize relatively away from pastoralism and towards (a) sedentary agriculture and (b) raiding expeditions across the frontier. Because of this, a constitutional exchange by which the nobility gave up its control of the land and its claim to military leadership while the freemen granted them regular agenda control over the public assembly made both freemen and nobility better off.

The Assembly of Warriors was constituted by all freemen; the Council of Leading Men by nobility. In Caesar's time, kings and commanders were both of the nobility. Alternatively, Tacitus described a Germania in which nobility took a backseat to military prowess and organizational skill in choosing the commanders of armed retinues. In the background, freemen also labored at husbandry and agriculture. In Caesar's time the Germans were largely pastoralists but Tacitus describes peoples who were to a greater extent focused on sedentary agriculture. From the freemen would also be drawn the supply of labor for military action and raiding. The Gauls were, to begin with, wealthier than the Germans to the West of the Rhine. Many Gallic countries had stable diplomatic and trade relationships with Rome. Notwithstanding this, at the conclusion of the Gallic War the Germans found themselves in contact with a frontier along which there were considerable sources of wealth. Feeding, equipping, and generally 
maintaining the frontier forces constituted big business in the Republic and, later on, also the Empire. Along the frontier, food, supplies, and money became present in hitherto unknown quantities. Tacitus is describing a Germania where the returns to raids had increased substantially since the days of Caesar's Gallic exploits. Heather (2010) relates the illustrative example of Vannius, a king of the Germanic Marcomanni confederation in the first century. Vannius became a frontier client of the Roman Empire, recognizing "the wealth-generating potential of making Germanic traders bring their goods to Roman merchants on his soil, so that he could charge tolls” (p. 139). However, in 50AD "his wealth was ransacked by a group of Germani from outside the frontier zone, who put together an expedition of sufficient strength to seize his assets” (p. 141).

At the same time, Rome was encroaching upon areas that had served as pressure valves for the growing populations of the relatively (to Gaul and Rome) pastoral Germania. Much of Germania was covered by dense forest that was very costly to clear. Facing scarcity of land suitable for husbandry and pastoral agriculture, Germanic peoples had often chosen to migrate westward across the Rhine. The establishment of the Roman frontier raised the costs associated with these migrations. Rome sought to regulate the settlement of barbarians within its provinces, and it also stood ready to protect existing settlements within its borders, making their displacement more costly than would previously have been the case for a Germanic army marching in search of, often quite literally, greener pastures. Deprived of the population pressure values, the relative returns to sedentary agriculture increased. A movement to sedentary agriculture provided relief from the demand for new lands. "This transformation, then, from a preeminently pastoral state to an agricultural state came about during the century after [the German’s] geographical expansion was arrested by the power of Rome” (Bury, 1967, p. 7). 
There are two occasions where Tacitus alludes to Germanic laziness, in regards to agriculture at least in part. First: the German "thinks it tame and spiritless to accumulate slowly by the sweat of his brow what can be got quickly by the loss of a little blood (Tacitus, ch. 14, pp. 113-114). Second: “The fact is that although [the Germans'] land is fertile and extensive, they fail to take full advantage of it because they do not work sufficiently hard” (Tacitus, ch. 26, p. 122). While one must be wary of picking and choosing which of Tacitus's statements to take seriously and which to dismiss, it is widely accepted that Roman ethnographers "employed a dichotomy between civilized and uncivilized, urban civilization and barbarians, as a basic tool in their analyses” (Burns, 2003, p.3). For Tacitus, this dichotomy served as a mirror by which Romans could examine their own morality - the low points and the high:

The Germans [as portrayed by Tacitus] are free of the vices or sophistication and cities. They are nonetheless barbarians, indolent, slothful, excessive drinkers, in the main wanting in direct intelligence. Like all barbarians, they cannot withstand unexpected trials and are fit only for sudden exertions, not for sustained labor (Fitzsimons, 1976, p. 478).

Through his portrayal, Tacitus hoped that the Germans' “customs may inspire Romans to return to their own earlier austerity and rigor [...]” (Fitzsimons, 1976, p. 478). Caesar undoubtedly employed a more or less similar dichotomy when he wrote about the Germans. The distinctions, then, between Tacitus' and Caesar's portrayals of Germanic governance institutions are likely to be more salient than similarities between their portrayals of Germanic temperaments.

Furthermore, when Tacitus notes that the German's "land is fertile and extensive” but that the barbarians do not "take full advantage of it" due to a lack of effort, this comments may be made in regards to the farming itself or to the labor necessary to clear arable land in the first 
place. The latter would be consistent with archaeological evidence that generally indicates the increasing importance of agriculture at the turn of the millennium. Todd (1975, p. 84) surveys evidence from an excavated settlement that was located in the coastal marshes found between the Weser and Elbe rivers:

In the late first century BC, the marshland [...] first became amenable to settlement. Arable farming is revealed in rough plough marks in the natural soil at this time, but the area was still vulnerable to flooding. No traces of buildings have been recovered from the beginnings of this phase. Near its end however, two substantial houses and a granary were constructed, and by the first century AD, seven or eight dwellings, of which four were substantial long-houses, and their attendant granaries, had appeared.

Todd (1975, pp. 87-88) further states:

No doubt before the marshes were actually settled they had been used for fishing, the catching of game, and perhaps as pasture grounds for cattle, but the determined onslaught upon them in the early Roman period was clearly made by settlers seeking new land and not by men who were merely developing activities already in progress there.

In Todd's (1975, p. 88) opinion: “The colonization of the marshland may then be an early indication that the land suitable for agriculture in these parts of Germania would one day prove inadequate for the needs of its population.” This archaeological evidence, of course, is not amenable to the sort of precise dating that would be ideal for the present analysis; also, the evidence is limited to the number of excavated sites. Again, however, Todd (1975, ch. 3) discusses a number of examples, including the Weser-Elbe marshlands settlement, that are 
generally consistent with the expansion of sedentary agriculture in the face of population pressures that were exacerbated by Rome's encroachment.

From Caesar to Tacitus, then, Germanic peoples saw increased incentives to allocate their resources and efforts away from pastoralism and towards both sedentary agriculture and raiding across the frontier into the Roman provinces. Caesar tells us that the leading men assigned land to tribes and clans (gentibus congnationibusque hominum) (Caesar, Book VI, p. 347). A system of annual land reallocation to tribes and clans, rather than individuals, may have worked well for husbandry. However, it may also have been an inefficient arrangement for sedentary agriculture where it is important for individual farmers to internalize the benefits to fertilization and crop rotation over time. Likewise, to the extent that raiding became more important, there would be benefits to choosing commanders based on organizational skill and military prowess rather than their noble birth. Notably, "Tacitus makes it clear that only military leadership had survived among those closest to Rome and that only those farthest away were still ruled purely by sacral kings” (Burns, 2003, p. 180). This indicates that raiding became a more important activity in proportion to the proximity to the Empire as defined by Caesar's conquests. Furthermore, movements towards sedentary agriculture and raiding were complementary to the extent that "the massive increase in food production that this revolution in agricultural production must have generated goes a long way towards explaining how the new military kings could support their retinues” (Heather, 2010, p. 51).

The changes described above would work to the benefit of the freemen relative to the nobility. The freemen provided the labor for both the production of food and violence. The nobility, alternatively, stood to lose their exclusive role in military leadership and their control over the allocation of land. The nobility were not the primary source of labor and were vastly 
outnumbered by the freemen. Relinquishing military and land-allocating roles would leave the Council of Leading Men without a well-defined role to play in Germanic society; and the (no longer exclusively noble) duces would render the reges nominal. ${ }^{17}$ The expanded range of freemen decision-making would be a source of external costs imposed on the nobility. In particular, they would have no say in either the decision to go to war or its execution once decided.

While the losses to the nobility associated with these constitutional changes were significant, the gains to the freemen were large enough to offer compensation. Congleton (2007, p. 270) notes that, within the King and Council template, "reform is possible whenever circumstances change and the [council] or the king can fully compensate the other for anticipated losses from new procedures and constraints”. In this context, the reforms to land allocation procedure and constraints on military election were made possible by compensations made to the Council of Leading Men by the Assembly of Warriors. This compensation took the form of agenda control in a regularly meeting Assembly.

Unfortunately, Tacitus does not describe the "major affairs" of the Assembly with anywhere near the desirable (from the perspective of this researcher) level of detail. Aside from law and order, the only public goods explicitly referred to are horses "kept at public expense" that provided omens to the community (Tacitus, ch. 10, p. 110). However, in the provision of law and order Tacitus notes: "The man who is found guilty has to pay a fine of so many horses or cattle, part of which goes to the king [regi] or the state, part to the victim of the wrongful act or to his relatives” (Tacitus, ch. 12, p. 111; emphasis added). This suggests that there were taxes

\footnotetext{
17 "With the replacement of tribal kings by kings of migrating armies, the representatives of the new kingship had to take on rights and responsibilities of the older form of rule" (Wolfram,1997, pp. 17-18). Wolfram is referring to the barbarian migrations of the fourth and fifth centuries, but his comments characterize where the evolution of Germanic kingship from Caesar to Tacitus was ultimately heading.
} 
collected. Furthermore, the Assembly chose "magistrates who administered justice in the districts and villages” (Tacitus, ch. 12, p. 111). These magistrates, then, presumably had a significant role to play in the amount of taxes (fines) that were collected, and perhaps what part of them went to "the king or the state". Though the interpretation of this is less clear, the following statement by Tacitus' statement is noteworthy: “It is a national custom for gifts of cattle or agricultural produce to be made to the chiefs [principibus], individual citizens making voluntary contributions for this purpose" (ch. 15, p. 114). If "voluntary" here refers to the unanimous decision by the freemen of the Assembly, then this again suggests that taxes were collected and were a source of income for the nobility.

The encroachment of Rome upon Germania effectively increased the tax base, and more so conditional on the constitutional reforms. In particular, the ability draw commanders from the entire free population - based on their organizational skills and military prowess - to lead armed retinues opened up opportunities to extract significant amounts of wealth from across the frontier. Control over the effective tax rates and the portion of taxes that went to the nobility would be of obvious benefit to Germania's principes. If taxes were constituted in large part by fines associated with criminal convictions, then having more regular (and therefore more frequent) opportunities for to hear charges would also benefit the leading men. Both of these ends were accomplished by the constitutional reforms whereby the Assembly of Warriors met (approximately) monthly to deliberate on agendas that were set by the Council of Leading Men.

As Congleton $(2007,2011$ a) demonstrates, agenda control is particularly valuable in an uncertain environment where policy preferences are likely to change. The encroachment of Rome created just such an environment. Agenda control for the Council of Leading Men would allow them to hold the status quo policies (by not allowing different policies to be considered) or 
to restrict the consideration of alternatives to those under which the nobility would not incur losses. From Caesar to Tacitus, new sources of wealth became available to the Germans; the tax base was growing. The Council of Leading Men stood to gain simply by holding the status quo on its privileges. The nobility could hold the line on tax rates and, as well, the part of total tax collections that they were able to extract for themselves.

The changes in Germanic governance institutions from $50 \mathrm{BC}$ to $50 \mathrm{AD}$ are made intelligible by a constitutional exchange. Rome’s expansion to its Rhinean and Danubian frontiers during the Gallic War exposed the Germanic peoples to new sources of wealth but also a harder constraint on available lands. The freemen stood to benefit from reallocating the resources and efforts away from pastoralism and towards raiding and sedentary agriculture. However, the nobility had exclusive access to positions of military leadership and control over the allocation of lands. What could the freemen (represented by the Assembly of Warriors) offer to the nobility (represented by the Council of Leading Men) in exchange for military leadership based on effectiveness and an end to yearly, village-level reallocations of land? The nobility played a large role in adjudicating criminal charges, and a claim on a part of any fines imposed; they essentially had the power to tax and to extract a part of the collections for themselves. If the Assembly of Warriors (where criminal charges were brought and heard) was to agree to meet more regularly and frequently, and to grant agenda control of those meetings to the Council of Leading Men, then both the freemen and nobility could improve their barbarian lots. That is precisely what we witness from Caesar to Tacitus.

One difficulty in achieving the constitutional exchanges described above would likely have involved the ability of the free population at large to effectively commit to accepting the status quo on taxation (Acemoglu, 2003). Freemen may have been willing to nominally grant the 
nobility agenda control in the assembly, but with the Council of Leading Men relinquishing control of land allocations individual freemen could more effectively exercise "exit options" and avoid the actual collection of fines. However, the encroachment of Rome and population pressures likely worked to alleviate the commitment problems. Individual freemen faced tighter constraints on their ability to "vote with their feet". This would have made the acquisition of agenda control in the Assembly of Warriors more meaningful to the nobility. Magistrates could have more easily administered justice and collected fines, securing the revenues due to the nobility.

\section{Concluding Discussion}

Western Civilization is in a meaningful sense derivative from, on the one hand, the Greek and Roman societies of classical antiquity and, on the other hand, those of Europe’s northern barbarians. The institutions of the former are well-documented relative to the latter. And, at least in part because this, the contribution of the latter to Western Civilization is probably less appreciated and understood than that of the former. Yet the latter may have left important and persistent marks on the West. For example, Banfield (1958) and Putnam (1993) both document the differential functioning of similar formal institutions (e.g., judicial systems) in northern versus southern Italy. One cultural root of this difference may be the Ostrogothic and Lombardian invasions and successor kingdoms in the north of modern Italy during the $5^{\text {th }}$ and $6^{\text {th }}$ centuries. $^{18}$

\footnotetext{
${ }^{18}$ This conjecture is consistent with Tabellini's (2010) evidence that exogenous (i.e., dating to at least before the $19^{\text {th }}$ century) component of culture is highly correlated with regional economic outcomes throughout Europe. Of course, there is a lot of room between the $5^{\text {th }}$ and $6^{\text {th }}$ centuries and before the $19^{\text {th }}$ century, so consistent with is the farthest one can go in relating Tabellini's results to Banfield and Putnam.
} 
This paper provides, to my knowledge, the first attempt to provide an economic analysis of barbarian institutions during the late Roman Republic and early Roman Empire and how they were involving. To do so I rely on the accounts of Julius Caesar (circa 50 BC) and Cornelius Tacitus (who used Pliny the Elder as a primary source, who wrote circa 50 AD). A number of historians have detailed the Germanic governance institutions as described in those accounts, as well as how those details change from Caesar to Tacitus. However, as best that I can tell, I am the first to do so with an economist's eye towards the decision-making rules and divisions of governance. Furthermore, I attempt to make the evolution of those governance institutions from Caesar to Tacitus intelligible with an analysis of constitutional exchanges motivated by changes in incentives that were precipitated by Caesar's conquest of Gaul.

By the time Tacitus wrote the Germania a number of changes in Germanic governance institutions had occurred. In particular, (1) temporary military commanders elected from the nobility yielded to standing retinues under the leadership of professional commanders; (2) public assemblies met more frequently and regularly; (3) councils made up of the nobility had acquired agenda control in the public assemblies; and (4) the nobility had relinquished their control over village land allocations. The constitutional exchanges were, I argue, beneficial to both the nobility and freemen of the northern barbarians. They made sense against a backdrop of incentives that had changed to favor a reallocation of resources away from pastoralism and towards sedentary farming and raiding excursions across the frontier. These incentives were shaped by the encroachment of Rome which brought, among other things, tighter constraints on the availability of land and new sources of wealth to potentially be extracted.

The purpose of this paper is to provide an initial attempt at understanding the Germanic governance institutions that (a few centuries later and with further evolution) that characterized 
the successor kingdoms to the Roman Empire. Even if these are better understood from Caesar to Tacitus, there is much to do in filling the lacunae from Tacitus to Gregory of Tours, Paul the Deacon, and Jordanes. And, of course, the ethnographers/historians of late antiquity and the early medieval period constitute just one set of sources from which insights can be gleaned. Other sources include archaeological evidence and the texts of barbarian law codes (e.g., the Lex Burgundionum and Lex Salica). In the case of the latter, the importance of legal traditions for modern economic outcomes had been widely recognized (e.g., La Porta et al. (1999); Glaesar and Schleifer (2002)) and the unexplored (by economists) barbarian codes may represent to explore how far the legacy of such traditions can be traced back in Western history. Opportunities clearly abound for future research. 
Table 1

Germanic governance institutions around $50 \mathrm{BC}$ and around $50 \mathrm{AD}$.

\begin{tabular}{|c|c|c|}
\hline & 50 BC (Caesar’s observations) & 50 AD (Tacitus’ observations) \\
\hline \multirow[t]{2}{*}{$\operatorname{Rex}$} & $\begin{array}{l}\text { A prominent member of the } \\
\text { leading men (principes). }\end{array}$ & $\begin{array}{l}\text { A prominent member of the leading } \\
\text { men (principes). }\end{array}$ \\
\hline & $\begin{array}{l}\text { Authority based on respect for } \\
\text { nobility and/or the sacral. }\end{array}$ & $\begin{array}{l}\text { Authority based on respect for nobility } \\
\text { and/or the sacral. }\end{array}$ \\
\hline \multirow[t]{4}{*}{ Dux } & $\begin{array}{l}\text { Elected from the reges (or } \\
\text { principes generally?). }\end{array}$ & $\begin{array}{l}\text { Exceptional military/organizational } \\
\text { skill. }\end{array}$ \\
\hline & Temporary tenures. & Indefinite tenures. \\
\hline & $\begin{array}{l}\text { Wars: elected by acclamation } \\
\text { (unanimity? supermajority?) }\end{array}$ & $\begin{array}{l}\text { Wars: provided defense services in } \\
\text { expectation of remuneration. }\end{array}$ \\
\hline & $\begin{array}{l}\text { Raids: elected unanimously (by } \\
\text { all who “promise their own } \\
\text { assistance”); pursued extractive } \\
\text { activities. }\end{array}$ & Raids: pursued extractive activities. \\
\hline \multirow[t]{5}{*}{ Assembly of Warriors } & All free men. & All free men. \\
\hline & $\begin{array}{l}\text { Met irregularly; to make } \\
\text { decisions during times of } \\
\text { emergency (war). }\end{array}$ & Met approximately monthly. \\
\hline & $\begin{array}{l}\text { Elected duces by acclamation } \\
\text { (unanimity? supermajority?). }\end{array}$ & $\begin{array}{l}\text { Decided major affairs by acclamation } \\
\text { (unanimity? supermajority?) }\end{array}$ \\
\hline & & $\begin{array}{l}\text { Adjudicated major criminal charges by } \\
\text { acclamation (unanimity? } \\
\text { supermajority?). }\end{array}$ \\
\hline & & Appointed village principes. \\
\hline \multirow[t]{3}{*}{ Council of Leading Men } & $\begin{array}{l}\text { The principes from various } \\
\text { tribes. }\end{array}$ & The principes from various tribes. \\
\hline & $\begin{array}{l}\text { Met once a year to allocate land; } \\
\text { otherwise during times of } \\
\text { emergency (war). }\end{array}$ & $\begin{array}{l}\text { Decisions on matters of minor } \\
\text { importance. }\end{array}$ \\
\hline & Could call Assembly to meet. & Set agenda at Assembly. \\
\hline
\end{tabular}




\section{References}

Acemoglu, D. 2003. Why not a political Coase theorem? social conflict, commitment, and politics. Journal of Comparative Economics 31, 620-652.

Banfield, E. C. 1958. The Moral Basis of a Backward Society. New York: Free Press.

Benson, B. L. 1990. The Enterprise of Law: Justice without the State. San Francisco: Pacific Research Institute for Public Policy.

Benson, B. L. 1994. Are public goods really common pools? considerations of the evolution of policing and highways in England. Economic Inquiry 32, 249-271.

Benson, B. L. 1998. To Serve and Protect: Privatization and Community in Criminal Justice. New York: New York University Press.

Buchanan, J. M. 1965. An economic theory of clubs. Economica 32, 1-14.

Buchanan, J. M. 1975. The Limits of Liberty. Chicago: University of Chicago Press.

Buchanan, J. M., Tullock, G. 1962. The Calculus of Consent. Indianapolis: Liberty Fund.

Burns, T. S. 2003. Rome and the Barbarians. Baltimore: Johns Hopkins Press.

Bury, J. B. 1967. The Invasion of Europe by the Barbarians. New York: W. W. Norton and Co.

Caesar, J., Edwards, H. J. 1939. The Gallic War. Cambridge: Harvard University Press.

Congleton, R. D. 2001. On the durability of King and Council: The Continuum between Dictatorship and Democracy. Constitutional Political Economy 12, 193-215.

Congleton, R. D. 2011. Perfecting Parliament: Constitutional Reform, Liberalism, and the Rise of Western Democracy. Cambridge: Cambridge University Press.

Congleton, R. D. 2011. Why local government do not maximize profits: on the value-added by the representative institutions of town and city governance. Public Choice 149, 187-201. de Jasay, A. 1985. The State. Indianapolis: Liberty Fund. 
de Jasay, A. 1990. Social Contract, Free Ride: A study of the Public Goods Problem. Oxford: Oxford University Press.

de Jasay, A. 1997. Against Politics: On Government, Anarchy, and Order. New York: Routledge.

Ekelund, R., Dorton, C. 2003. Criminal justice institutions as a common pool: the $19^{\text {th }}$ century analysis of Edwin Chadwick. Journal of Economic Behavior and Organization 50, 271294.

Evans-Pritchard, E. E., 1947. The Nuer. Oxford: Clarendon Press.

Fink, A. 2011. Under what conditions may social contracts arise? evidence from the Hanseatic League. Constitutional Political Economy 22, 173-190.

Fitzsimons, M. A. 1976. The mind of Tacitus. Review of Politics 38, 473-493.

Glaesar, E. L., Shleifer, A. 2002. Legal origins. Quarterly Journal of Economics 117, 1193-1229.

Greenwood, T. 1936. History of the Germans: Barbaric Period. London: Longman, Rees, Orme, and Co.

Gudeman, A. 1900. The sources of the Germania of Tacitus. Transactions and Proceedings of the American Philological Association 31, 93-111.

Haverfield, F. 1912. The Romanization of Roman Britain ( $2^{\text {nd }}$ ed). Oxford: Clarendon Press (Kindle Edition; Public Domain E-Book).

Heather, P. 2006. The Fall of the Roman Empire: A New History of Rome and the Barbarians. Oxford: Oxford University Press.

Heather, P. 2010. Empires and Barbarians: The Fall of Rome and the Birth of Europe. Oxford: Oxford University Press.

Kirzner, I. M. 1973. Competition and Entrepreneurship. Chicago: University of Chicago Press.

La Porta, R., Lopez-de-Silanes, F., Shleifer, A., Vishny, R. 1999. The quality of government. 
Journal of Law, Economics, \& Organization 15, 222-279.

Leeson, P. T. 2007. Efficient anarchy. Public Choice 130, 41-53.

Leeson, P. T. 2007. An-arrgh-chy: the law and economics of pirate organization. Journal of Political Economy 115, 1049-1094.

Leeson, P. T. 2009. The calculus of piratical choice: the myth of the myth of the social contract. Public Choice 139, 443-459.

Leeson, P. T. 2009. The Invisible Hook: The Hidden Economics of Pirates. Princeton: Princeton University Press.

Leeson, P. T. 2011. Government, clubs, and constitutions. Journal of Economic Behavior and Organization 80, 301-308.

Nozick, R. 1974. Anarchy, State, and Utopia. New York: Basic Books.

Olson, M. 1993. Dictatorship, democracy, and development. American Political Science Review 87, 567-576.

Posner, E. A. 2010. The constitution of the Roman Republic: a political economy perspective. SSRN Working Paper (http://papers.ssrn.com/sol3/papers.cfm?abstract_id=1701981).

Powell, B., Stringham, E. P. 2009. Public choice and the economic analysis of anarchy. Public Choice 140, 503-538.

Price, A. H. 1968. Differential Germanic social structures. Vierteljahrschrift für Sozial und Wirtschaftsgeschichte 55, 433-448.

Putnam, R. B. 1993. Making Democracy Work: Civic Tradition in Modern Italy. Princeton: Princeton University Press.

Rawls, J. 1999. A Theory of Justice: Revised Edition. Cambridge: Harvard University Press.

Rothbard, M. N. 1998. The Ethics of Liberty. New York: New York University Press. 
Sandler, T., Tschirhart, J. 1997. Club theory: thirty years later. Public Choice 93, 335-355.

Skarbek, D. 2011. Putting the "con” into constitutions: the economics of prison gangs. Journal of Law, Economics, and Organization 26, 183-211.

Tabellini, G. 2010. Culture and conditions: economic development in the regions of Europe. Journal of the European Economic Association 8, 677-716.

Tacitus, G. C., Church, A. J., Brodribb, W. J. 1869. The Germania of Tacitus. London and Cambridge: Macmillan and Co.

Tacitus, G. C., Mattingly, H., Handford, S. A. 1970. The Agricola and the Germania. London: Penguin Books.

Todd, M. 1975. The Northern Barbarians: 100 BC - AD 300. Oxford: Basil Blackwell.

Thompson, E. A. 1965. The Early Germans. Oxford: Clarendon Press.

Wolfram, H. 1997. The Roman Empire and Its Germanic Peoples. (Dunlap. T, translation) Berkley and Los Angeles: University of California Press. 